\title{
Direct arylation polycondensation for synthesis of bithiophene-based alternating copolymers
}

Junpei Kuwabara, ${ }^{\dagger}$ Yuta Nohara,${ }^{\dagger}$ Seong Jib Choi, ${ }^{\dagger}$ Yohei Fujinami,${ }^{\dagger}$ Wei Lu, ${ }^{\dagger}$ Ken Yoshimura, ${ }^{\dagger}$ Jun Oguma ${ }^{\ddagger}$ Katsuhiro Suenobu, ${ }^{\S}$ Takaki Kanbara ${ }^{*} \dagger$

${ }^{\dagger}$ Tsukuba Research Center for Interdisciplinary Materials Science (TIMS), Graduate School of Pure and Applied Sciences, University of Tsukuba, 1-1-1 Tennodai, Tsukuba 305-8573, Japan

\$sukuba Material Development Laboratory, Sumitomo Chemical Co., Ltd., 6 Kitahara, Tsukuba 300-3294, Japan

${ }^{\S}$ Advanced Materials Research Laboratory, Sumitomo Chemical Co., Ltd., 6 Kitahara, Tsukuba 300-3294, Japan

\begin{abstract}
:
Direct arylation polycondensation reactions using a simple catalytic system gave eight kinds of bithiophene-based alternating copolymers. The conditions for the reactions of $3,3^{\prime}, 4,4^{\prime}$-tetramethylbithiophene with dibromoarylenes were optimized to obtain high-molecular-weight polymers without formation of cross-linked structures. In the reaction of a dibromoarylene containing a reactive $\mathrm{C}-\mathrm{H}$ bond, a short reaction
\end{abstract}


time $(1.5 \mathrm{~h})$ was suitable for preventing side reactions. In contrast, a long reaction time (6 h) gave high-molecular-weight polymers from dibromoarylene monomers without a reactive $\mathrm{C}-\mathrm{H}$ bond. This polycondensation reaction enables the synthesis of polymers containing dye structures such as diketopyrrolopyrrole and isoindigo, which are applicable as materials for polymer solar cells.

\section{Introduction}

A bithiophene unit is one of the most important components of $\pi$-conjugated polymers for optoelectronic materials because it gives good charge mobility to the corresponding polymers ${ }^{1}$ and serves as an appropriate donor unit in donor-acceptor polymers with a low bandgap. ${ }^{2}$ A considerable number of bithiophene-based polymers have therefore been developed as materials for polymer solar cells (PSCs), ${ }^{2}$ organic light-emitting diodes, ${ }^{3}$ and organic field-effect transistors (OFETs). ${ }^{4}$ In particular, bithiophene-based polymers containing dye structures such as diketopyrrolopyrrole derivatives exhibit high performances in PSCs $^{5}$ and OFETs. ${ }^{6}$ Although bithiophene-based polymers can be synthesized by chemical or electrochemical oxidation reactions, most bithiophene-based polymers for optoelectronic materials are synthesized by polycondensation via cross-coupling reactions such as the Suzuki-Miyaura and Migita-Kosugi-Stille cross-coupling reactions. ${ }^{7}$ 
Polycondensation via dehydrohalogenative cross-coupling reactions, so-called direct arylation, ${ }^{8}$ has recently become widely recognized as a method for synthesizing $\pi$-conjugated polymers. ${ }^{9-15}$ We previously reported the direct arylation polycondensation of an alkylated bithiophene with dibromofluorene analogs using a simple catalytic system; the reaction with $\mathrm{Pd}(\mathrm{OAc})_{2}$ and pivalic acid in a phosphine-free system for $3 \mathrm{~h}$ gave the corresponding polymer with a high molecular weight in good yield. ${ }^{13 a}$ Since direct arylation polycondensation does not require prior preparation of organometallic monomers and does not produce stoichiometric amounts of metal-containing wastes, direct arylation polycondensation is expected to be an efficient synthetic method for a variety of functional bithiophene-based conjugated polymers, compared with polycondensation using conventional cross-coupling reactions. However, this synthetic method is difficult to completely avoid a side reaction at unexpected $\mathrm{C}-\mathrm{H}$ bonds, which leads to formation of branched or cross-linked structures because all aromatic $\mathrm{C}-\mathrm{H}$ bonds in a monomer have a potential for direct arylation reactions. ${ }^{12-14}$ Since the number of expected $\mathrm{C}-\mathrm{H}$ bonds for direct arylation decreases with increasing degree of polymerization, a reaction for too long time causes the overreactions at unexpected $\mathrm{C}-\mathrm{H}$ bonds. Therefore, appropriate reaction time is needed to be determined in direct arylation polycondensation to avoid overreactions and 
to obtain high-molecular-weight polymers. We investigated optimization of the reaction conditions, especially in terms of reaction time, for the synthesis of bithiophene-based conjugated polymers. Base on the results, dye-containing polymers were synthesized and evaluated as materials for PSCs.

\section{Results and Discussion}

Optimization of Reaction Conditions and Synthesis. In a previous report, the polycondensation reaction of $3,3^{\prime}, 4,4^{\prime}$-tetramethylbithiophene with 2,7-dibromo-9,9-dioctylfluorene for $3 \mathrm{~h}$ gave Polymer 1 with a high molecular weight $\left(M_{\mathrm{n}}=31800\right)$ in good yield $(91 \%)^{13 \mathrm{a}}$ (Scheme 1 ; Table 1 , entry 1$)$ The methyl groups on the bithiophene monomer provided selective direct arylation at its $\alpha$ position. To adapt this method for use with a variety of monomers, including dye-containing monomers, the reaction conditions, especially reaction time, were re-examined. The reaction for synthesis of Polymer $\mathbf{1}$ in a shorter reaction time was investigated because large amounts of polymeric products were precipitated out from the reaction mixture before the reaction time reached $3 \mathrm{~h}$. Using the same catalytic system, the reaction for 1.5 h gave Polymer 1 with a molecular weight of 32100 in 93\% yield (Table 1, entry 2).

This result, which was similar to that obtained for a reaction time of $3 \mathrm{~h}$, showed that 
the polycondensation reaction proceeded to completion in $1.5 \mathrm{~h}$. In contrast to the reaction of 2,7-dibromo-9,9-dioctylfluorene, the polycondensation reaction of 2,7-dibromo- $N$-octadecylcarbazole for $3 \mathrm{~h}$ gave insoluble products as well as the soluble Polymer 2 in low yield (Table 1, entry 3). The formation of insoluble products indicates the presence of cross-linked structures caused by undesired side-reactions at $\mathrm{C}-\mathrm{H}$ bonds. ${ }^{12-14}$ High reactivities of the $\mathrm{C}-\mathrm{H}$ bonds at the 3 and 6 positions in carbazole derivatives in direct arylation have been reported, ${ }^{16}$ so reactions at these $\mathrm{C}-\mathrm{H}$ bonds were likely to form cross-linked structures. The large polydispersity $\left(M_{\mathrm{w}} / M_{\mathrm{n}}>\right.$ 5) of the soluble fraction was consistent with the predicted cross-linked structures. In the reaction for 1.5 h, Polymer 2 with a molecular weight of 26000 was obtained in $96 \%$ yield without formation of insoluble products (Table 1, entry 4). Negligible branched structures were detected by MALDI-TOF-MS (See Supporting Information, Figure S1). This improved result indicates that direct arylation at the aromatic $\mathrm{C}-\mathrm{H}$ bonds in the 3,3',4,4'-tetramethylbithiophene moiety proceeded preferentially over those at the $\mathrm{C}-\mathrm{H}$ bonds in the carbazole moiety, in the early stage of the reaction, i.e., before 1.5 h. Since the number of aromatic $\mathrm{C}-\mathrm{H}$ bonds in the 3,3',4,4'-tetramethylbithiophene moiety decreases with increasing degree of polymerization, the undesirable reactions at $\mathrm{C}-\mathrm{H}$ bonds in the carbazole moiety occur at relatively high frequencies in the late stage 
of the polycondensation reaction, resulting in the formation of cross-linked structures. The reaction time is therefore an important factor in direct arylation polycondensation to avoid overreactions at unexpected $\mathrm{C}-\mathrm{H}$ bonds. The reaction of 3,6-dibromo- $N$-octadecylcarbazole for $3 \mathrm{~h}$ yielded Polymer 3 with a moderate molecular weight (7300), without formation of insoluble products (Table 1, entry 5). The extension of the reaction time to $6 \mathrm{~h}$ increased the yield and the molecular weight of the polymer (Table 1, entry 6). A similar trend was observed in the syntheses of Polymers 4 and 5 (Table 1, entries 7-10). The nitrogen atoms at the para position to the $\mathrm{C}-\mathrm{Br}$ group are likely to decrease the reaction rate. Although 1,4-dibromo-2,5-dioctylbenzene possesses steric hindrance of the octyl groups at the ortho position to the $\mathrm{C}-\mathrm{Br}$ group, the polycondensation reaction with 3,3',4,4'-tetramethylbithiophene yielded the soluble Polymer 6 in moderate yield (Table 1, entry 11). The reaction for $6 \mathrm{~h}$ provided a higher molecular weight and yield than that for $3 \mathrm{~h}$ (Table 1, entry 12).

Since these simple dibromoarylenes can be used as monomers for direct arylation polycondensations, polycondensation reactions of dibromoarylenes containing diketopyrrolopyrrole ${ }^{17}$ and isoindigo ${ }^{18}$ structures were conducted to synthesize materials for PSCs. The polycondensation reaction of the dibromo-substituted 
diketopyrrolopyrrole derivative gave Polymer 7 with a molecular weight of 18100 in 96\% yield (Table 1, entry 13). Since Polymer 7 had low solubility in $N, N$-dimethylacetamide (DMAc), the product was precipitated out in $0.5 \mathrm{~h}$ at the standard concentration $(0.30 \mathrm{M})$. The details for optimization of the concentration are shown in the Supporting Information (Table S-1). The reaction was therefore conducted under diluted conditions $(0.15 \mathrm{M})$. Polymer 7 was purified by Soxhlet extraction to remove the oligomeric products, which were of low solubility and difficult to remove by simple washing. A polymer with an isoindigo moiety, Polymer 8, was obtained using the polycondensation reaction under the optimized conditions (Table 1, entry 14).

Characterization. The characterizations of Polymers 1-4 and Polymer 6 were reported in a previous study. ${ }^{13 \mathrm{a}}$ The ${ }^{1} \mathrm{H}$ NMR spectra of the polymers, synthesized under the modified conditions, were almost identical to the reported spectra (see Supporting Information). The optimization of the reaction conditions provided polymers with higher molecular weights in increased yields without changing the structures. The newly synthesized polymers, Polymer 5, 7, and 8, were characterized using ${ }^{1} \mathrm{H}$ and ${ }^{13} \mathrm{C}\left\{{ }^{1} \mathrm{H}\right\}$ NMR spectroscopies. Figure 1 shows the ${ }^{1} \mathrm{H}$ NMR spectrum of 
Polymer 7. Each signal can be assigned to the repeating unit, and the signal of the terminal units was observed at $6.98 \mathrm{ppm}$. These results indicate that Polymer 7 has a linear structure without defects such as branched or cross-linked structures. Characterization of Polymer 7 was also conducted using MALDI-TOF-MS (Figure S2). The spectrum exhibits peaks corresponding to alternating structures with terminal $\mathrm{C}-\mathrm{H}$

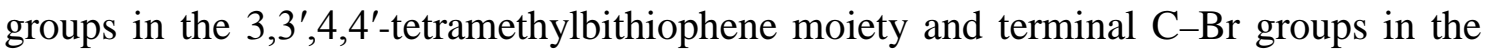
diketopyrrolopyrrole moiety. There are no peaks corresponding to a branched structure in the mass spectrum, supporting the proposed linear structure of Polymer 7. In contrast, the mass spectrum of Polymer $\mathbf{8}$ exhibits peaks corresponding to a branched structure; this structure may be caused by direct arylation reactions at the $\mathrm{C}-\mathrm{H}$ bonds in the isoindigo moiety (Figure S3).

Photophysical Properties. Table 2 summarizes the photophysical properties of Polymers 1-8. Polymers 1-6 have similar absorptions in the solution and thin-film states. In contrast, Polymers $\mathbf{7}$ and $\mathbf{8}$ exhibit red shifts of their absorptions in the film state compared with the solution state, presumably as a result of donor-acceptor structures leading to strong $\pi-\pi$ stacking interactions. Figure 2 shows the UV-Vis absorption spectra of Polymers 1, 7, and $\mathbf{8}$ in the solution state. The introduction of 
dye moieties into the main chain resulted in absorptions in the long-wavelength region.

Polymers with similar structures to those of Polymers $\mathbf{7}$ and $\mathbf{8}$ have been reported in the literature (DPP-DT and IID-DT, Figure 3). ${ }^{17 a, 18 a} \quad$ These polymers have a bithiophene unit instead of the 3,3',4,4'-tetramethylbithiophene unit. The maximum absorption wavelengths of DPP-DT and IID-DT are 580 and $701 \mathrm{~nm}$ in thin film state, respectively; these are at longer wavelengths than those of Polymers $\mathbf{7}$ and $\mathbf{8}$ (520 and $580 \mathrm{~nm})$, respectively. ${ }^{17 \mathrm{a}, 18 \mathrm{a}}$ These observations indicate that the methyl groups on the tetramethylbithiophene induce a twisted structure as a result of their steric hindrance, leading to decreases in the coplanarities and the conjugation lengths of the polymers. In particular, the difference between the maximum absorption wavelengths of Polymer 8 and IID-DT was significant $(121 \mathrm{~nm})$. These results indicate that the impact on the absorption properties of donor-acceptor interactions between the bithiophene unit and the isoindigo unit through $\pi$-conjugation is more significant than interactions between the bithiophene and diketopyrrolopyrrole units.

Electrochemical Properties and Photovoltaic Performances. The electrochemical properties of Polymers $\mathbf{7}$ and $\mathbf{8}$ were investigated using cyclic voltammetry (Figure S4). The oxidation-onset potentials of Polymers $\mathbf{7}$ and $\mathbf{8}$ were 
$0.67 \mathrm{~V}$ and $0.70 \mathrm{~V}$ vs. the ferrocene/ferrocenium couple, respectively. On the basis of these potentials, the highest occupied molecular orbital (HOMO) energy levels of Polymers 7 and $\mathbf{8}$ were estimated to be -5.47 and $-5.50 \mathrm{eV} .^{17 \mathrm{a}}$ These values are close to those obtained from photoelectron spectroscopy measurements (Table 3). Similarly, the lowest unoccupied molecular orbital (LUMO) energy levels were estimated to be -3.15 and $-3.51 \mathrm{eV}$ from the cyclic voltammograms. The electrochemical bandgaps of Polymers $\mathbf{7}$ and $\mathbf{8}$ were larger than those of the corresponding reference polymers (DPP-DT and IID-DT). ${ }^{17 a, 18 a}$ These trends are consistent with the absorption properties of the polymers.

Since Polymers $\mathbf{7}$ and $\mathbf{8}$ have wide absorptions in the visible region and low-energy HOMO levels, these polymers are expected to be suitable as materials for PSCs. ${ }^{19}$ The photovoltaic performances of Polymers 7 and 8 were investigated in bulk heterojunction solar cells with the configuration glass/indium tin oxide (ITO)/poly(3,4-ethylenedioxythiophene):poly(styrenesulfonate) (PEDOT:PSS)/Polymer 7 or 8:methyl[6,6]phenyl-C61-butylate $(\mathrm{PC} 61 \mathrm{BM}) / \mathrm{TiO}_{x} / \mathrm{Al}$. The details of the devices are described in the Experimental Section. The photovoltaic results are shown in Figure 4 and Table 4 . The edges of the external quantum efficiency (EQE) curves of the devices are in accordance with the absorption edges of the polymers. The 
similarities of the EQE responses and the absorption properties demonstrate that Polymers $\mathbf{7}$ and $\mathbf{8}$ served as active materials for exciton formation by light absorption. Although the power conversion efficiency (PCE) values are lower than those of typical P3HT-based devices, ${ }^{2}$ these results are important for the point that direct arylation polycondensation can be used to synthesize materials for PSCs. ${ }^{14 \mathrm{c}}$ It is notable that the devices with Polymer 7 or $\mathbf{8}$ both showed a high open-circuit voltage $\left(V_{\text {oc }}\right)$ of $1.01 \mathrm{~V}$. These high $V_{\mathrm{oc}}$ values provably result from the low HOMO levels of Polymers $\mathbf{7}$ and $\mathbf{8}$, because the $V_{\text {oc }}$ value is known to be proportional to the difference between the energies of the LUMO level of PC61BM and the HOMO level of a p-type polymer. ${ }^{19}$ The low short-circuit current density $\left(J_{\mathrm{sc}}\right)$ and fill factor may be attributed to the twisted structure of the polymer, which is identified from the absorption properties, as described above, because a twisted structure is unfavorable for carrier transport. ${ }^{20}$ Indeed, a DPP-DT-based device of similar configuration had a PCE of $1.67 \%$ with a $J_{\text {sc }}$ of 7.8 $\mathrm{mA} / \mathrm{cm}^{2}{ }^{17 \mathrm{a}}$ The calculations also support the suggestion that steric hindrance of the methyl groups on the tetramethylbithiophene unit causes the twisted structure of the main chain (Figure S5). ${ }^{21}$ These methyl groups were introduced to prevent side reactions at the relatively active $\mathrm{C}-\mathrm{H}$ bonds at the $\beta$ positions of the bithiophene moieties. $^{13 a}$ These results clarify the next challenge; high regioselectivity is needed to 
be developed in the development of direct arylation polycondensations, to enable rational design of $\pi$-conjugated polymers.

\section{Conclusions}

Direct arylation polycondensation reactions using a simple catalytic system gave eight kinds of bithiophene-based alternating copolymers. Reaction time was an important factor for obtaining high-molecular-weight polymers without the formation of cross-linked structures. This polycondensation reaction gave dye-containing polymers that are applicable as materials for PSCs. To obtain high-performance materials efficiently, further development of this methodology, especially in terms of $\mathrm{C}-\mathrm{H}$ bond selectivity, is underway.

\section{Experimental Section}

Materials. 2,7-dibromo-9,9-dioctylfluorene, $\mathrm{Pd}(\mathrm{OAc})_{2}, \mathrm{~K}_{2} \mathrm{CO}_{3}$, and other chemicals were received from commercial suppliers and used without further purification. Anhydrous DMAc were purchased from Kanto Chemical and used as a dry solvent. PC61BM was purchased from Frontier Carbon Corporation. PEDOT:PSS (CleviosTM P VP AI 4083) were purchased from Heraeus. 
$3,3^{\prime}, 4,4^{\prime}$-tetramethylbithiophene, ${ }^{22}$

2,7-dibromo- $N$-octadecylcarbazole, ${ }^{13 a}$

3,6-dibromo- $N$-octadecylcarbazole, ${ }^{13 a}$

2,8-dibromo-10,10-dioctyl- $N$-methylphenazasiline, ${ }^{23}$

3,7-dibromo-10-

(2-ethylhexyl)phenothiazine, ${ }^{24}$

1,4-dibromo-2,5-dioctylbenzene, ${ }^{25}$

$2,5-\mathrm{di}-$

(2-ethylhexyl)-3,6-bis(4-bromophenyl)pyrrolo[3,4-c]pyrrole-1,4-dione, ${ }^{26}$ and

-6,6'-dibromo-1,1'-bis(2-hexyldecyl)-[3,3'-biindolinylidene]-2,2'-dione ${ }^{27}$ were

prepared according to the literature methods.

General Methods. ${ }^{1} \mathrm{H}$ and ${ }^{13} \mathrm{C}\left\{{ }^{1} \mathrm{H}\right\}$ NMR spectra were recorded on a Bruker AVANCE-400 NMR spectrometer and Bruker AVANCE-600 NMR spectrometer, respectively. ${ }^{1} \mathrm{H}$ and ${ }^{13} \mathrm{C}\left\{{ }^{1} \mathrm{H}\right\}$ NMR spectra were measured with tetramethylsilane (TMS) as internal standard. Gel permeation chromatography (GPC) measurements were carried out on a SHIMADZU prominence GPC system equipped with polystyrene gel columns, using $\mathrm{CHCl}_{3}$ as an eluent after calibration with polystyrene standards. All manipulations for the reactions were carried out under nitrogen atmosphere using a standard Schlenk technique. Column chromatography was carried out with silica gel 60 (Kanto, 40-100 $\mu \mathrm{m}$, neutral). MALDI-TOF-MS spectra were recorded on AB SCIEX MALDI TOF/TOF 5800 using dithranol as a matrix. The measurements of the 
ionization potential were carried out on Riken Keiki Co., Ltd.; AC-2. Electrochemical measurements were performed by ALS Model 1200A Electrochemical Analyzer (BAS Inc.) with a standard three-electrode configuration. The polymer-coated ITO glass electrode was used as the working electrode. $\operatorname{Bu}_{4} \mathrm{NPF}_{6}(0.10 \mathrm{M})$ in acetonitrile was used as a supporting electrolyte with a platinum plate auxiliary electrodes. All measurements were carried out under a nitrogen atmosphere, and potentials were related to an $\mathrm{Ag} / \mathrm{Ag}^{+}$reference electrode. The potentials were calibrated with ferrocene/ferrocenium redox couple. Molecular geometries were fully optimized at the B3LYP/3-21G* level with the Gaussian09 program. ${ }^{[21]}$

Synthesis of Polymer 5. A mixture of $\mathrm{Pd}(\mathrm{OAc})_{2}(2.2 \mathrm{mg}, 0.010 \mathrm{mmol})$, pivalic acid $(0.017 \mathrm{~mL}, 0.15 \mathrm{mmol}), \mathrm{K}_{2} \mathrm{CO}_{3}(173 \mathrm{mg}, 1.3 \mathrm{mmol}), 3,7$-dibromo-10(2-ethylhexyl)phenothiazine (234 mg, $0.50 \mathrm{mmol}), 3,3^{\prime}, 4,4^{\prime}-$ tetramethylbithiophene (111 mg, $0.50 \mathrm{mmol})$ were stirred in anhydrous DMAc $(1.67 \mathrm{~mL})$ for $6 \mathrm{~h}$ at $100{ }^{\circ} \mathrm{C}$ under nitrogen atmosphere. After cooling to room temperature, the mixture was poured into an aqueous solution of ethylenediaminetetraacetic acid disodium salt $(\mathrm{pH}=$ 8). The suspension was stirred overnight at room temperature. The precipitate was separated by filtration and washed with $0.1 \mathrm{M} \mathrm{HCl}$ solution, distilled water, $\mathrm{MeOH}$, and 
hexane. The precipitate was dissolved in $\mathrm{CHCl}_{3}$ and the solution was filtered through a plug of Celite to remove insoluble material. A reprecipitation from $\mathrm{CHCl}_{3} / \mathrm{MeOH}$ gave Polymer 5 as pale yellow solid in $98 \%$ yield. $M_{\mathrm{n}}=21000, M_{\mathrm{w}} / M_{\mathrm{n}}=2.80 .{ }^{1} \mathrm{H}$ NMR (400 MHz, $\left.\mathrm{CDCl}_{3}\right): \delta 0.87(\mathrm{t}, J=7.2 \mathrm{~Hz}, 6 \mathrm{H}), 0.91(\mathrm{t}, J=7.2 \mathrm{~Hz}, 6 \mathrm{H}), 1.20-1.61$ (br, 8H), 1.99 (br, 1H), 2.12 (s, 6H), 2.22 (s, 6H), 3.77 (br, 2H), 6.91 (d, J = 8.4 Hz, 2H), 7.26 (br, 4H). ${ }^{13} \mathrm{C}\left\{{ }^{1} \mathrm{H}\right\} \mathrm{NMR}\left(100 \mathrm{MHz}, \mathrm{CDCl}_{3}\right): \delta 144.6,137.2,137.0,133.3,129.2$, $128.2,128.1127 .9,125.4,115.7,51.0,35.8,30.7,28.6,24.0,23.1,14.4$ 14.1, 14.0, 10.5 .

Synthesis of Polymer 7. The polycondensation reaction of 2,5-di(2-ethylhexyl)-3,6-bis(4-bromophenyl)pyrrolo[3,4-c]pyrrole-1,4-dione (335 mg, 0.50 mmol) and 3,3',4,4'-tetramethylbithiophene (111 $\mathrm{mg}, 0.50 \mathrm{mmol})$ was carried out by according to the above mentioned method. The product was subjected to Soxhlet extraction with hexane and $\mathrm{CHCl}_{3}$. A reprecipitation of the $\mathrm{CHCl}_{3}$ fraction in $\mathrm{MeOH}$ gave Polymer 7 as red solid in $96 \%$ yield. $M_{\mathrm{n}}=18100, M_{\mathrm{w}} / M_{\mathrm{n}}=2.35 . \quad{ }^{1} \mathrm{H}$ NMR $(400$ $\left.\mathrm{MHz}, \mathrm{CDCl}_{3}\right): \delta 0.75(\mathrm{t}, J=7.4 \mathrm{~Hz}, 6 \mathrm{H}), 0.81(\mathrm{t}, J=7.2 \mathrm{~Hz}, 6 \mathrm{H}), 1.00-1.30(\mathrm{br}, 16 \mathrm{H})$, 1.50-1.60 (br, 2H), $2.18(\mathrm{~s}, 6 \mathrm{H}), 2.33(\mathrm{~s}, 6 \mathrm{H}), 3.82(\mathrm{~s}, 4 \mathrm{H}), 7.65(\mathrm{~d}, J=8.4 \mathrm{~Hz}, 4 \mathrm{H})$, $7.89(\mathrm{~d}, J=8.0 \mathrm{~Hz}, 4 \mathrm{H}) . \quad{ }^{13} \mathrm{C}\left\{{ }^{1} \mathrm{H}\right\} \mathrm{NMR}\left(125 \mathrm{MHz}, \mathrm{CDCl}_{3}\right) \quad \delta 162.9,148.2,137.84$, $137.80,137.5,137.2,134.7,129.2,129.0,127.2,110.0,45.1,38.6,30.4,28.3,23.8$, 
$22.9,14.42,14.37,14.0,10.5$.

Synthesis of Polymer 8. The polycondensation reaction of (E) -6,6'-dibromo-1,1'-bis(2-hexyldecyl)-[3,3'-biindolinylidene]-2,2'-dione (322 mg, 0.5 mmol) and 3,3',4,4'-tetramethylbithiophene (111 $\mathrm{mg}, 0.50 \mathrm{mmol})$ was carried out by according to the above mentioned method for Polymer 5 giving Polymer 8 as pale green solid in $82 \%$ yield. $M_{\mathrm{n}}=11300, M_{\mathrm{w}} / M_{\mathrm{n}}=2.76 .{ }^{1} \mathrm{H}$ NMR $\left(400 \mathrm{MHz}, \mathrm{CDCl}_{3}\right): \delta$ $0.90(\mathrm{t}, J=6.6 \mathrm{~Hz}, 6 \mathrm{H}), 0.96(\mathrm{t}, J=7.2 \mathrm{~Hz}, 6 \mathrm{H}), 1.20-1.55(\mathrm{br}, 16 \mathrm{H}), 1.80-2.00$ (br, 2H), 2.19 (s, 6H), $2.35(\mathrm{~s}, 6 \mathrm{H}), 3.73(\mathrm{~s}, 4 \mathrm{H}), 6.92(\mathrm{~s}, 2 \mathrm{H}), 7.19(\mathrm{~d}, J=8.4 \mathrm{~Hz}, 2 \mathrm{H}), 9.21$ $(\mathrm{d}, J=8.4 \mathrm{~Hz}, 2 \mathrm{H}) . \quad{ }^{13} \mathrm{C}\left\{{ }^{1} \mathrm{H}\right\} \mathrm{NMR}\left(125 \mathrm{MHz}, \mathrm{CDCl}_{3}\right) \quad \delta 168.7,145.4,138.7,138.2$, 138.1, 134.9, 132.4, 129.8, 129.3, 122.7, 120.7, 108.5, 44.3, 37.8, 30.9, 28.9, 24.2, 23.1, $14.6,14.5,14.1,10.9$.

\section{Photovoltaic Device Fabrication.}

A dispersion of PEDOT:PSS in water $\left(\right.$ Clevios $^{\text {TM }}$ P VP AI 4083) was spun cast onto a clean ITO substrate, which was washed with acetone and irradiated under UV light and ozone gas for $20 \mathrm{~min}$ to decompose the impurities, and then baked at $200{ }^{\circ} \mathrm{C}$ for $10 \mathrm{~min}$. To a polymer $(1.0 \mathrm{wt} \%)$ solution of $o^{-}$-dichlorobenzene were added PC61BM (double weight vs polymer), then the mixture was stirred for $1 \mathrm{~h}$ at ambient temperature. The 
resulting solution was applied to the surface of a PEDOT:PSS coated ITO plate by the spincoating method at a thickness of ca. $100 \mathrm{~nm}$. After drying under vacuum for 20 min, titanium(IV) isopropoxide solution $(0.35 \mathrm{wt} \%$ in isopropanol) was spincoated. The resulting plate was placed in a vacuum chamber and the surface was coated with the aluminum electrode $(100 \mathrm{~nm})$ by evaporation at $10^{-4} \mathrm{~Pa}$ at room temperature. Finally, the solar cell was completed by encapsulation. The PCE values were obtained using Bunko Keiki CEP-2000 (AM1.5G, $100 \mathrm{~mW} / \mathrm{cm}^{2}$ ).

\section{Author Information}

Notes

The authors declare no competing financial interest.

Supporting Information Available: Spectroscopic data. This information is available free of charge via the Internet at http://pubs.acs.org/.

\section{Acknowledgement.}

The authors thank the Chemical Analysis Center of University of Tsukuba for the measurements of NMR and MALDI-TOF-MS. This work was partly supported by 
the Collaborative Research Program of Institute for Chemical Research, Kyoto University and Industrial Technology Research Grant Program in 2011 from New

Energy and Industrial Technology Development Organization (NEDO) of Japan.

\section{References and Notes}

(1) (a) H. Sirringhaus, T. Kawase, R. H. Friend, T. Shimoda, M. Inbasekaran, W. Wu and E. P. Woo, Science 2000, 290, 2123-2126; (b) N. Stutzmann, R, H. Friend and H. Sirringhaus, Science 2003, 299, 1881-1884.

(2) (a) Y.-J. Chen, S.-H. Yang and C.-S. Hsu, Chem. Rev. 2009, 109, 5868-5923; (b) P.-L. T. Boudreault, A. Najari and M. Leclerc, Chem. Mater. 2011, 23, 456-469; (c) A. Facchetti, Chem. Mater. 2011, 23, 733-758.

(3) A. C. Grimsdale, K. L. Chan, R. E. Martin, P. G. Jokisz and A. B. Holmes, Chem. Rev. 2009, 109, 897-1091.

(4) Y. Liu, Y. Liu and X. Zhan, Macromol. Chem. Phys. 2011, 212, 428-443.

(5) (a) B. Tieke, A. R. Rabindranath, K. Zhang and Y. Zhu, Beilstein J. Org. Chem. 2010, 6, 830-845; (b) V. S. Gevaerts, A. Furlan, M. M. Wienk, M. Turbiez and R. A. J. Janssen; $A d v$. Mater. 2012, 24, 2130-2134; (c) M. M. Wienk, M. Turbiez, J. Gilot and R. A. J. Janssen, $A d v$. Mater. 2008, 20, 2556-2560.

(6) (a) J. S. Ha, K. H. Kim and D. H. Choi, J. Am. Chem. Soc. 2011, 133, 10364-10367; (b) Y. Li, P. Sonar, S. P. Singh, M. S. Soh and M. van Meurs, J. Tan, J. Am. Chem. Soc. 2011, 133, 2198-2204.

(7) (a) T. Yamamoto, Bull. Chem. Soc. Jpn. 2010, 83, 431-455; (b) J. Sakamoto, M. Rehahn, G. Wegner and A. D. Schlüter, Macromol. Rapid Commun. 2009, 30, 653-687; (c) B. Carsten, F. He, H. J. Son, T. Xu and L. Yu, Chem. Rev. 2011, 111, 1493-1528.

(8) (a) L. Ackermann, R. Vicente and A. R. Kapdi, Angew. Chem., Int. Ed. 2009, 48, 9792-9826; (b) F. Bellina and R. Rossi, Tetrahedron 2009, 65, 10269-10310; (c) D. Lapointe and K. Fagnou, Chem. Lett. 2010, 39, 1118-1126; (d) B. Liégault, D. Lapointe, L. Caron, A. Vlassova and K. Fagnou, J. Org. Chem. 2009, 74, 1826-1834.

(9) A. Facchetti, L. Vaccaro and A. Marrocchi, Angew. Chem., Int. Ed. 2012, 51, 3520-3523.

(10) a) Q. Wang, R. Takita, Y. Kikuzaki and F. Ozawa, J. Am. Chem. Soc. 2010, 132, 11420-11421;

b) Q. Wang, M. Wakioka and F. Ozawa, Macromol. Rapid Commun. 2012, 33, 1203-1207.

(11) a) P. Berrouard, A. Najari, A. Pron, D. Gendron, P.-O. Morin, J.-R. Pouliot, J. Veilleux and M. Leclerc, Angew. Chem., Int. Ed. 2012, 51, 2068-2071; (b) S. Beaupré, A. Pron, S. H. Drouin, A. Najari, L. G. Mercier, A. Robitaille and M. Leclerc, Macromolecules 2012, 45, 6906-3614; (c) 
P. Berrouard, S. Dufresne, A. Pron, J. Veilleux and M. Leclerc, J. Org. Chem. 2012, 77, 8167-8173; (d) N. Allard, A. Najari, J.-R. Pouliot, A. Pron, F. Grenier and M. Leclerc, Polym. Chem., 2012, 3, 2875-2879.

(12) (a) W. Lu, J. Kuwabara and T. Kanbara, Macromolecules, 2011, 44, 1252-1255; (b) W. Lu, J. Kuwabara, T. Iijima, H. Higashimura, H. Hayashi and T. Kanbara, Macromolecules, 2012, 45, 4128-4133.

(13) (a) Y. Fujinami, J. Kuwabara, W. Lu, H. Hayashi and T. Kanbara, ACS Macro Lett., 2012, 1, 67-70; (b) W. Lu, J. Kuwabara, and T. Kanbara, Polym. Chem. 2012, DOI: 10.1039/c2py20539d; (c) K. Yamazaki, J. Kuwabara and T. Kanbara, Macromol. Rapid Commun. 2012, DOI: 10.1002/marc.201200550

(14) (a) S. Kowalski, S. Allard and U. Scherf, ACS Macro Lett. 2012, 1, 465-468; (b) A. E. Rudenko, C. A. Wiley, S. M. Stone, J. F. Tannaci and B. C. Thompson, J. Polym. Sci. Part A: Polym. Chem. 2012, 50, 3691-3697; (c) S.-W. Chang, H. Waters, J. Kettle, Z.-R. Kuo, C-H. Li, C.-Y. Yu, M. Horie, Macromol. Rapid Commun. 2012, DOI: 10.1002/marc.201200368.

(15) A. Mori et al. reported C-H functionalization polycondensation of 2-halo-3-alkylthiophenes using magnesium amide for a deprotonation. (a) S. Tamba, S. Mitsuda, F. Tanaka, A. Sugie and A. Mori, Organometallics, 2012, 31, 2263-2267; (b) S. Tamba, K. Shono, A. Sugie and A. Mori, J. Am. Chem. Soc. 2011, 133, 9700-9703; (c) S. Tamba, S. Tanaka, Y. Okubo, H. Meguro, S. Okamoto and A. Mori, Chem. Lett. 2011, 40, 398-399.

(16) H.-Q. Do and O. Daugulis, J. Am. Chem. Soc. 2011, 133, 13577-13586.

(17) (a) W. Li, T. Lee, S. J. Oh and C. R. Kagan, ACS Appl. Mater. Interfaces 2011, 3, 3874-3883;

(b) L. Chen, D. Deng, Y. Nan, M. Shi, P. K. L. Chan and H. Chen, J. Phys. Chem. C 2011, 115, 11282-11292; (c) C. Kanimozhi, P. Balraju, G. D. Sharma and S. Patil, J. Phys. Chem. B 2010, 114, 3095-3103; (d) Y. Zhu, I. Heim and B. Tieke, Macromol. Chem. Phys. 2006, 207, 2206-2214.

(18) (a) T. Lei, Y. Cao, X. Zhou, Y. Peng, J. Bian and J. Pei, Chem. Mater. 2012, 24, 1762-1770; (b) E. Wang, Z. Ma, Z. Zhang, K. Vandewal, P. Henriksson, O. Inganäs, F. Zhang and M. R. Anderson, J. Am. Chem. Soc. 2011, 133, 14244-14247; (c) R. Stalder, C. Grand, J. Subbiah, F. So and J. R. Reynolds, Polym. Chem. 2012, 3, 89-92.

(19) (a) M. C. Scharber, D. Mühlbacher, M. Koppe, P. Denk, C. Waldauf, A. J. Heeger and C. J. Brabec, Adv. Mater. 2006, 18, 789-794; (b) R. L. Uy, S. C. Price and W. You, Macromol. Rapid Commun. 2012, 33, 1162-1177; (c) H. Zhou, L. Yang and W. You, Macromolecules 2012, 45, 607-632.

(20) (a) H. Zhou, L. Yang, S. Xiao, S. Liu and W. You, Macromolecules 2010, 43, 811-820; (b) Q. Shi, H. Fan, Y. Liu, J. Chen, L. Ma, W. Hu, Z. Shuai, Y. Li and X. Zhan, Macromolecules 2011, 44, 4230-4240.

(21) Gaussian 09, Revision A.1, M. J. Frisch, G. W. Trucks, H. B. Schlegel, G. E. Scuseria, M. A. Robb, J. R. Cheeseman, G. Scalmani, V. Barone, B. Mennucci, G. A. Petersson, H. Nakatsuji, M. Caricato, X. Li, H. P. Hratchian, A. F. Izmaylov, J. Bloino, G. Zheng, J. L. Sonnenberg, M. Hada, M. Ehara, K. Toyota, R. Fukuda, J. Hasegawa, M. Ishida, T. Nakajima, Y. Honda, O. Kitao, H. 
Nakai, T. Vreven, J. A. Montgomery, Jr., J. E. Peralta, F. Ogliaro, M. Bearpark, J. J. Heyd, E. Brothers, K. N. Kudin, V. N. Staroverov, R. Kobayashi, J. Normand, K. Raghavachari, A. Rendell, J. C. Burant, S. S. Iyengar, J. Tomasi, M. Cossi, N. Rega, J. M. Millam, M. Klene, J. E. Knox, J. B. Cross, V. Bakken, C. Adamo, J. Jaramillo, R. Gomperts, R. E. Stratmann, O. Yazyev, A. J. Austin, R. Cammi, C. Pomelli, J. M. Ochterski, R. L. Martin, K. Morokuma, V. G. Zakrzewski, G. A. Voth, P. Salvador, J. J. Dannenberg, S. Dapprich, A. D. Daniels, Ö. Farkas, J. B. Foresman, J. V. Ortiz, J. Cioslowski and D. J. Fox, Gaussian, Inc., Wallingford CT, 2009.

(22) M. Zagorska and B. Krische, Polymer 1990, 31, 1379-1383.

(23) H. Hayashi, H. Nakao, S.-y. Onozawa, A. Adachi, T. Hayashi and K. Okita, Polym. J. 2003, 35, 704-710.

(24) G. Sang, Y. Zou and Y. Li, J. Phys. Chem. C 2008, 112, 12058-12064.

(25) R. Matthias, S. A. Dieter and F. W. James, Synthesis 1988, 386-388.

(26) (a) D. Cao, Q. Liu, W. Zeng, S. Han, J. Peng and S. Liu, J. Polym. Sci., Part A: Polym. Chem. 2006, 44, 2395-2405. (b) A. R. Rabindranath, Y. Zhu, I. Heim and B. Tieke, Macromolecules 2006, 39, 8250-8256.

(27) R. Stalder, J. Mei and J. R. Reynolds, Macromolecules 2010, 43, 8348-8352. 


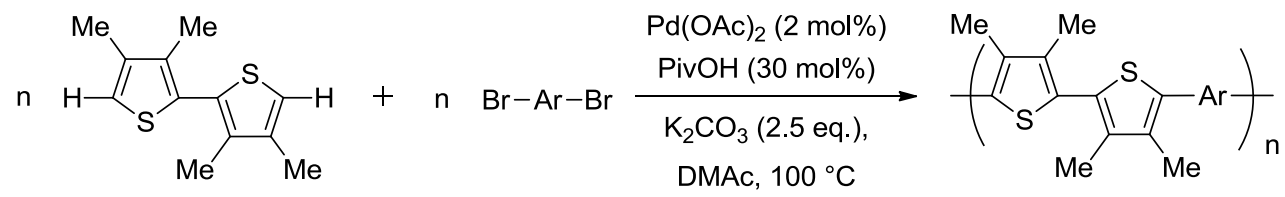

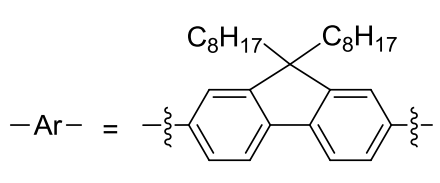

Polymer 1

Polymer 5<smiles>CCN1c2ccc(C)cc2Sc2cc(C)ccc21</smiles>

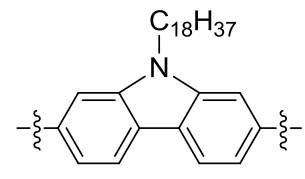

Polymer 2

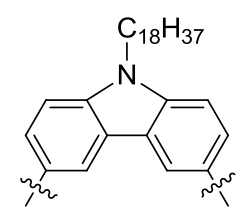

Polymer 3<smiles>CN1c2ccc(I)cc2[Si](C)([PH-])c2cc(I)ccc21</smiles>

Polymer 4<smiles>[Y]c1ccc(C2=C3C(=O)N(C=C)C(c4cc[Y]([Y])([H])cc4)=C3C(=O)N2CC)cc1</smiles>

Polymer 7<smiles>[Y]c1ccc2c(c1)N(C)C(=O)/C2=C1/C(=O)N(CF)c2cc([Y6])ccc21</smiles>

Polymer 8

Scheme 1 Polycondensation of 3,3',4,4'-tetramethylbithiophene and various dibromo-aromatic compounds. EH indicates a 2-ethylhexyl group. 
Table 1. Results of the polycondensation reactions ${ }^{\mathrm{a}}$

\begin{tabular}{|c|c|c|c|c|c|}
\hline Entry & Polymer & $\begin{array}{l}\text { Reaction } \\
\text { time(h) }\end{array}$ & $M_{\mathrm{n}}^{\mathrm{b}}$ & $M_{\mathrm{w}} / M_{\mathrm{n}}^{\mathrm{b}}$ & Yield $(\%)^{\mathrm{c}}$ \\
\hline $1^{\mathrm{g}}$ & Polymer 1 & $3 \mathrm{~h}$ & 31800 & 2.46 & 91 \\
\hline 2 & Polymer 1 & $1.5 \mathrm{~h}$ & 32100 & 2.34 & 93 \\
\hline $3^{g}$ & Polymer 2 & $3 \mathrm{~h}$ & 32900 & 5.36 & 47 \\
\hline 4 & Polymer 2 & $1.5 \mathrm{~h}$ & 26000 & 2.76 & 96 \\
\hline $5^{g}$ & Polymer 3 & $3 \mathrm{~h}$ & 7300 & 2.13 & 81 \\
\hline 6 & Polymer 3 & $6 \mathrm{~h}$ & 11700 & 1.93 & 99 \\
\hline $7^{g}$ & Polymer 4 & $3 \mathrm{~h}$ & 19200 & 2.90 & 88 \\
\hline 8 & Polymer 4 & $6 \mathrm{~h}$ & 27100 & 2.82 & 98 \\
\hline 9 & Polymer 5 & $3 \mathrm{~h}$ & 14400 & 2.44 & 86 \\
\hline 10 & Polymer 5 & $6 \mathrm{~h}$ & 21000 & 2.80 & 98 \\
\hline $11^{\mathrm{g}}$ & Polymer 6 & $3 \mathrm{~h}$ & 13500 & 1.95 & 65 \\
\hline 12 & Polymer 6 & $6 \mathrm{~h}$ & 15000 & 1.69 & $88^{\mathrm{d}}$ \\
\hline $13^{f}$ & Polymer 7 & $6 \mathrm{~h}$ & 18100 & 2.35 & $96^{\mathrm{e}}$ \\
\hline 14 & Polymer 8 & $6 \mathrm{~h}$ & 11300 & 2.76 & 82 \\
\hline
\end{tabular}

${ }^{a}$ Reactions were carried out at $100{ }^{\circ} \mathrm{C}$ using $\mathrm{Pd}(\mathrm{OAc})_{2}(2 \mathrm{~mol} \%)$, PivOH (30 mol\%) and $\mathrm{K}_{2} \mathrm{CO}_{3}$ (2.5 equiv.) in DMAc. ${ }^{\mathrm{b}}$ Estimated by GPC calibrated on polystyrene standards. ${ }^{\mathrm{c}}$ The products were obtained by reprecipitation from $\mathrm{CHCl}_{3} / \mathrm{MeOH}$ and washing with hexane. ${ }^{\mathrm{d}}$ Without washing with hexane. ${ }^{\mathrm{e}}$ Yield after Soxhlet extraction with hexane and acetone. ${ }^{\mathrm{f}}$ The concentration of the monomer was $0.15 \mathrm{M} .{ }^{\mathrm{g}}$ reference $13 \mathrm{a}$.

Table 2. Optical properties and energy level of polymers

\begin{tabular}{cccccc}
\hline Polymer & $\begin{array}{c}\lambda_{\max }(\mathrm{nm})^{\mathrm{a}} \\
\text { (solution) }\end{array}$ & $\begin{array}{c}\lambda_{\max }(\mathrm{nm}) \\
\text { (thin film) }\end{array}$ & $\begin{array}{c}\lambda_{\mathrm{eg}}(\mathrm{nm}) \\
\text { (thin film) }^{\mathrm{b}}\end{array}$ & $\begin{array}{c}\lambda_{\mathrm{em}}(\mathrm{nm})^{\mathrm{a}, \mathrm{c}} \\
(\text { solution })\end{array}$ & $E_{\mathrm{g}}{ }^{\text {opt }}(\mathrm{eV})^{\mathrm{d}}$ \\
\hline Polymer 1 & 368 & 364 & 414 & 468 & 2.99 \\
Polymer 2 & 370 & 370 & 414 & 467 & 2.99 \\
Polymer 3 & 319 & 319 & 390 & 460 & 3.18 \\
Polymer 4 & 359 & 359 & 412 & 463 & 3.01 \\
Polymer 5 & 310 & 310 & 418 & 430 & 2.97 \\
Polymer 6 & 328 & $\mathrm{e}$ & 381 & 484 & 3.25 \\
Polymer 7 & 502 & 520 & 600 & 586 & 2.07 \\
Polymer 8 & 574 & 585 & 713 & $\mathrm{f}$ & 1.74 \\
\hline
\end{tabular}

${ }^{\mathrm{a}}$ In $\mathrm{CHCl}_{3} .{ }^{\mathrm{b}}$ Absorption edge. ${ }^{\mathrm{c}}$ Maximum emission wavelength. ${ }^{\mathrm{d}}$ Optical bandgap from the absorption edge. ${ }^{\mathrm{e}}$ Broad absorption. ${ }^{\mathrm{f}}$ Negligible emission. 
Table 3. Electrochemical properties of Polymer 7, 8 and the reference polymers

\begin{tabular}{|c|c|c|c|c|}
\hline Polymer & $E_{\text {HOMO }}(\mathrm{eV})^{\mathrm{a}}$ & $E_{\text {НОMO }}{ }^{\mathrm{CV}}(\mathrm{eV})^{\mathrm{b}}$ & $E_{\mathrm{LUMO}}^{\mathrm{CV}}(\mathrm{eV})^{\mathrm{b}}$ & $E_{\mathrm{g}}^{\mathrm{CV}}(\mathrm{eV})$ \\
\hline Polymer 7 & -5.46 & -5.47 & -3.15 & 2.32 \\
\hline DPP-DT ${ }^{17 a}$ & & -5.4 & -3.5 & 1.9 \\
\hline Polymer 8 & -5.55 & -5.50 & -3.51 & 1.99 \\
\hline IID-DT ${ }^{18 a}$ & & -5.65 & -3.78 & 1.87 \\
\hline
\end{tabular}

Table 4. Photovoltaic properties of Polymer 7 and 8

\begin{tabular}{ccccc}
\hline Polymer & $V_{\mathrm{oc}} / \mathrm{V}$ & $J_{\mathrm{SC}} / \mathrm{mA} \mathrm{cm}^{-2}$ & $\mathrm{FF} / \%$ & $\mathrm{PCE} / \%$ \\
\hline Polymer 7 & 1.01 & 2.93 & 0.30 & 0.89 \\
Polymer 8 & 1.01 & 1.53 & 0.25 & 0.39 \\
\hline
\end{tabular}




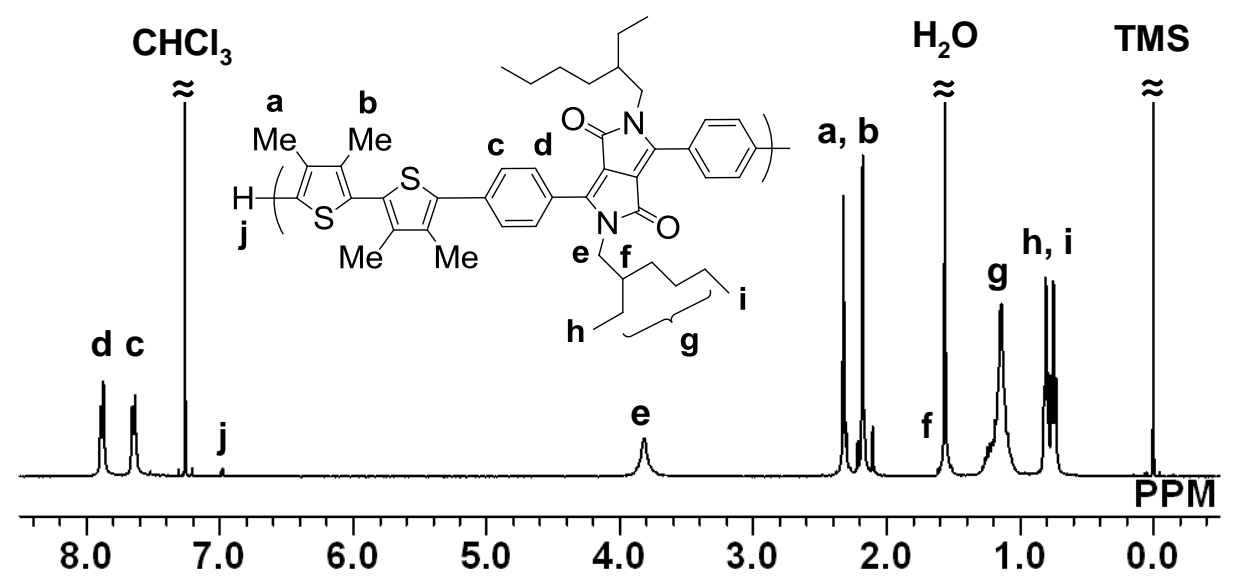

Figure 1. ${ }^{1} \mathrm{H}$ NMR spectrum of Polymer $7\left(400 \mathrm{MHz}, \mathrm{CDCl}_{3}\right)$.

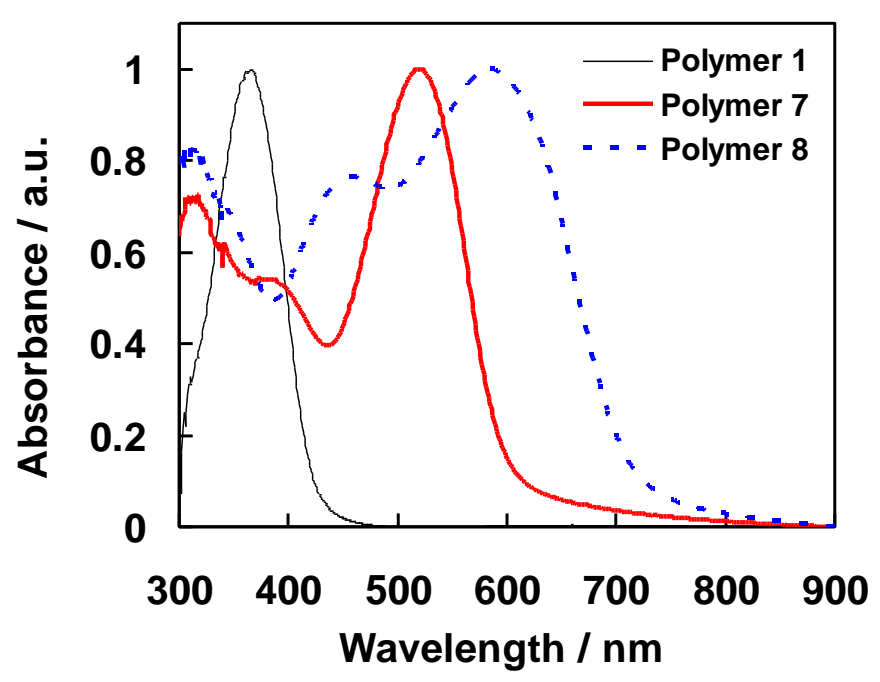

Figure 2. UV-Vis absorption spectrum of Polymer 1, 7, and $\mathbf{8}$ in the thin film state.

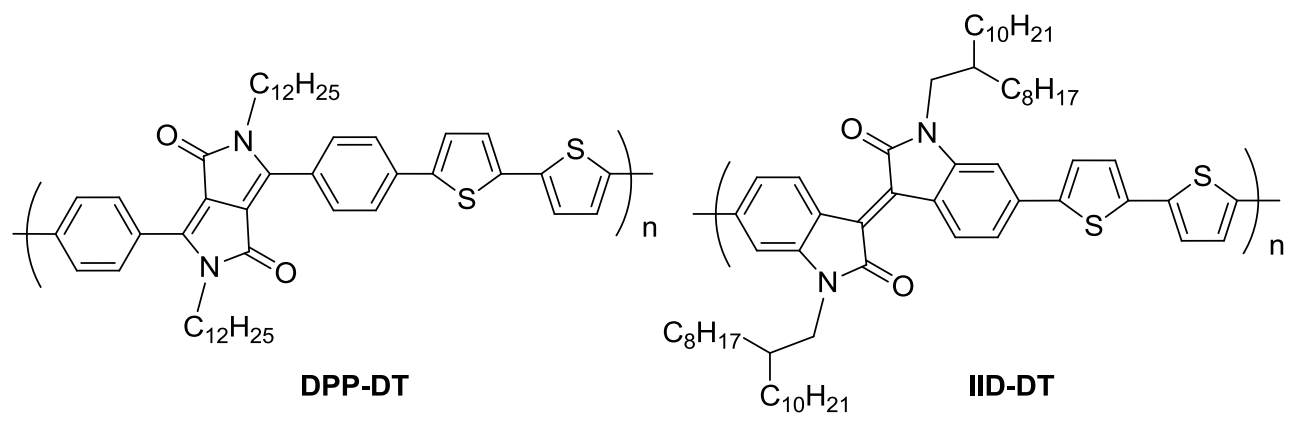

Figure 3. Structures of the reference polymers. 

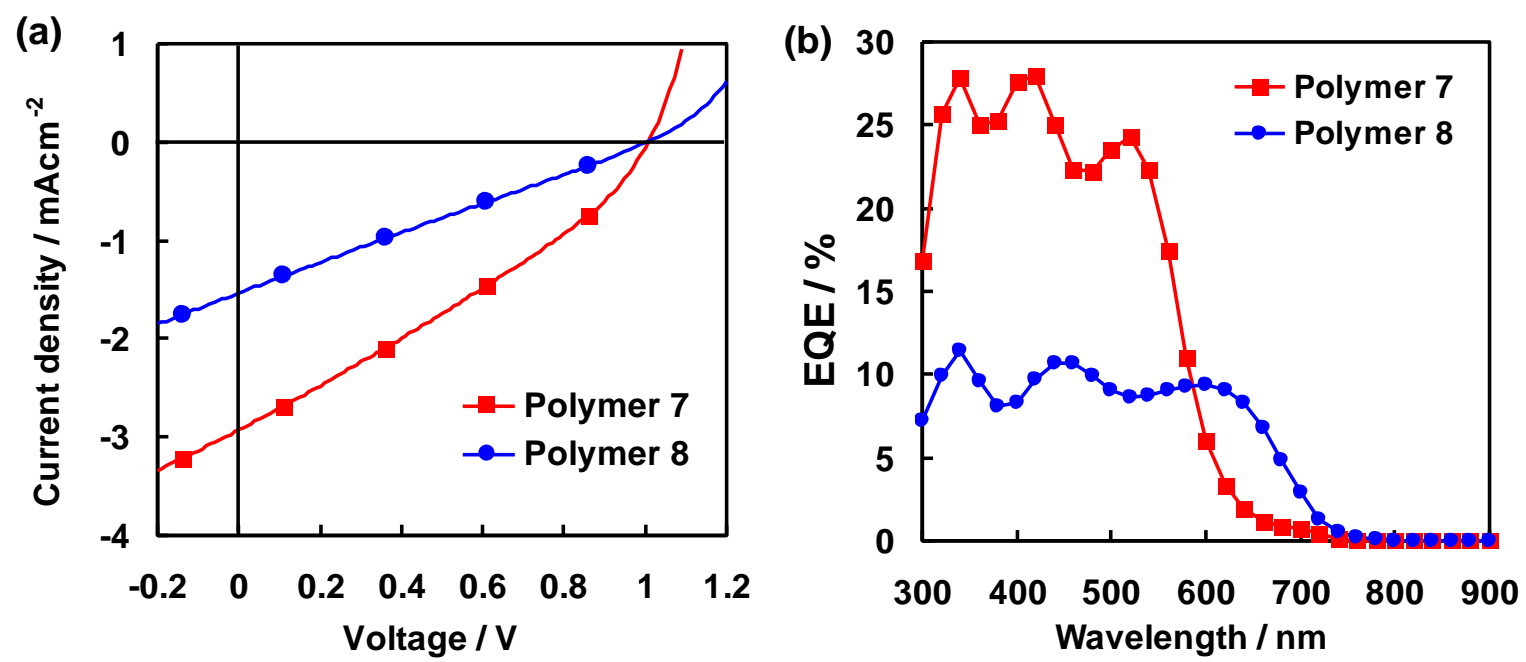

Figure 4. (a) $J-V$ and (b) EQE curves of the devices with Polymer 7 and Polymer 8. 


\section{Graphical Abstruct}

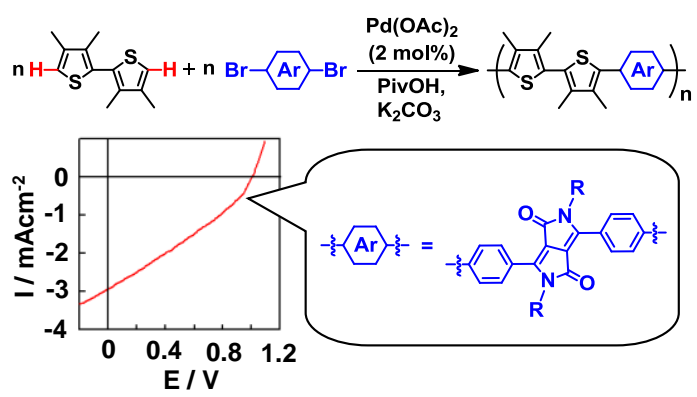

Direct arylation polycondensation gave bithiophene-based conjugated polymers serving as materials for polymer solar cells. 